\title{
Pickup Device
}

National Cancer Institute

\section{Source}

National Cancer Institute. Pickup Device. NCI Thesaurus. Code C50100.

An electromagnetic device designed to convert movement to an electric signal. 